\title{
LA CONTRAPUBLICIDAD ELECTORAL COMO CATEGORÍA DE LA COMUNICACIÓN POLÍTICA
}

\section{ELECTORAL SUBVERTISING: POLITICAL COMMUNICATION CATEGORY}

\author{
Mariela Castro Ávila*
}

RESUMEN

El artículo pretende concebir a la contrapublicidad como una herramienta de Comunicación Política (en tanto que ideológica) y por tanto, en una forma de resistencia de los movimientos sociales, las organizaciones no gubernamentales y personas individuales para denunciar y en el mejor de los casos, modificar ciertas conductas sociales, particularmente aquellas de orden consumista, en este caso de los productos electorales: las y los candidatos y sus propuestas.

PALABRAS CLAVE: ELECCIONES * PUBLICIDAD * CONTRAPUBLICIDAD * COMUNICACIÓN * POLÍTICA

ABSTRACT

This article is conceiving the subvertising as a Political Communication tool. Furthermore, as an ideology, is a way of social resistance used by social movements, non-governmental organizations and individuals. This Subvertising is an ideal to denounce and modify social behaviors, specially the consumerism behaviors, including the electoral consumerism.

KEY WORDS: ELECTIONS * ADVERTISING * SUBVERTISING * COMMUNICATION * POLITICS

Instituto de Formación y Estudios en Democracia

del Tribunal Supremo de Elecciones.

mcastroavila@gmail.com 


\section{INTRODUCCIÓN}

La contrapublicidad ha sido una herramienta utilizada desde los años 40 por los movimientos de contracultura, particularmente con las pintadas de vallas publicitarias en Estados Unidos. Esta ha evolucionado y se ha introducido en diversos espacios, particularmente en Internet, donde la denuncia se plantea como una necesidad para diversos colectivos sociales y personas que la ejercitan, por ejemplo, en sus blogs críticos.

Aunque la producción de contrapublicidad es innumerable, más aún a partir de la aparición de Internet, la teorización sobre este recurso no ha sido igualmente numerosa, particularmente en el marco de la Comunicación Política y más concretamente sobre contrapublicidad electoral.

Hasta hoy, el estudio de la contrapublicidad electoral no ha sido un tema considerado dentro de la Comunicación Política y por tanto, la propuesta de este artículo es ahondar en las posibilidades que tienen este tipo de actividades comunicativas de integrarse como una categoría explicativa de la Comunicación Política, en vista de que al querer denunciar y en el mejor de los casos, transformar las prácticas consumistas, están fuertemente cargadas de contenido político e ideológico. El artículo busca responder: ¿Cuál es el significado de la contrapublididad electoral como parte de la Comunicación Política?, ¿cuáles son las líneas de intersección entre ambos conceptos?, ¿qué objetivos tiene la contrapublicidad electoral? y ¿qué procedimientos emplea la contrapublicidad electoral?

La realización del artículo implicó la revisión documental sobre los temas para la construcción teórica de la propuesta, desenmarañando al menos parte de los procesos de significación social de las imágenes. Se realizó una evaluación de algunas imágenes de contrapublicidad electoral, con la idea de entender los procedimientos, los objetivos, los recursos utilizados y los mensajes difundidos.

\section{ALGUNOS CONCEPTOS CLAVES}

Los conceptos contrapublicidad $y$ comunicación política, a pesar de poseer una amplia elaboración teórica y ejemplos prácticos, carecen de un abordaje conjunto, ya que después de una búsqueda es evidente que la contrapublicidad electoral, no es vista ni como categoría ni como herramienta de la Comunicación Política.

Lo que sí es claramente abundante, particularmente en Internet, es la producción de contrapublicidad en temas de Comunicación Política, particularmente (aunque no exclusivamente) de propaganda o publicidad electoral.

\section{PUBLICIDAD Y PROPAGANDA}

Históricamente ha existido un amplio debate sobre estos conceptos, sin embargo, la línea divisoria ha tendido a difuminarse hasta el punto de no existir, debido por un lado a la cultura de mercado y de consumo que ha impactado a toda la sociedad llegando a "identificar a la sociedad actual como la 'sociedad de consumo"' (Sassatelli, 2007:1), por el otro, la tendencia mundial a partir de la posguerra, ha llevado a asociar el término de propaganda con "la comunicación política contraria a los sistemas democráticos” (Herreros, 1989:309).

La contrapublicidad como categoría conceptual trata de hacer evidente, para la persona receptora de la publicidad el uso de los mecanismos publicitarios de persuasión, pero también de denunciar las cantidades millonarias que pagan las empresas, los partidos políticos o los candidatos por la publicidad en medios de comunicación. Más importante aún, hacer ver a los ciudadanos que ellos son vistos como consumidores donde su dinero o su voto es lo que interesa.

Para comprender el concepto de la contrapublicidad se debe entender el concepto al cual se opone: la publicidad. La publicidad es una de las áreas de la Comunicación Social 
$y$ su objetivo fundamental es el de persuadir o convencer al público para que adquiera determinados productos; esto mediante el uso de recursos estilísticos y soportes mediáticos, que presentan aquello que se anuncia como algo deseable y necesario para el consumidor. Sassatelli señala que:

... la publicidad y los varios aspectos de la comercialización de bienes (...) se encuentran ocupados construyendo significados alrededor del producto para hacerlo consumible (significante para el consumidor) calzándolo con la estructura de necesidades, e inevitablemente modificando y expandiendo los deseos $y$ necesidades (2007: 4).

La persona llega, gracias a la publicidad, a identificarse con las imágenes y modelos, justamente porque fueron elegidos para que eso suceda. De igual modo, la publicidad electoral busca que la gente se identifique con la o el candidato y con sus propuestas, $y$ que su gusto $y$ deseo se transforme en el voto.

El mecanismo que utiliza la publicidad para generar esa persuasión en la gente es la asociación de determinados valores $y$ contenidos a un producto, para imponer una imagen determinada, no del producto que se anuncia, ni de la realidad concreta en que se origina, sino del sistema de valores (consumistas e irracionales) de la sociedad actual. Así, los anuncios construyen su propia realidad, reproduciendo y transformando la existente, convirtiéndose en un mecanismo generador de cultura cotidiana que hace que "el espectador se sienta marginalmente insatisfecho con su manera actual de vivir, no con la forma de vida de la sociedad, sino con la suya propia dentro de ésta" (Romero, 2005).

Desde este punto de vista, no existe mayor diferencia entre la publicidad comercial $y$ la publicidad electoral, ya que el objetivo de ambas es el de persuadir, en el caso de la primera, persuadir para que se adquiera un bien o un servicio, en la segunda, de persuadir para votar por una opción política.

Desde una visión crítica, la publicidad es vista como aquello que:
... transmite valores como el hedonismo, la competitividad o el individualismo; porque éstos incitan más al consumo e incrementan las ventas. Pero estos valores forman parte de una estructura ideológica más compleja, (...) que propone el consumo como respuesta, no a nuestras necesidades, sino a las aspiraciones que la propia cultura de consumo construye (CHM, 2009: 6).

La publicidad ha llegado a perfeccionarse en su objetivo y por tanto ha superado la idea de la venta del producto como fin último, su propósito es modificar la mentalidad de la gente $y$ con ello generar la actitud y el comportamiento de los consumidores, según sus expectativas y el trasfondo de esta nueva forma es fundamentalmente ideológico. Así lo ha asegurado Luciano Benetton en la Revista Mundo en el 2001: "No vendo ropa en mis campañas sino una ideología. [...] Si hiciéramos publicidad sobre el producto, llegaríamos a un público limitado. En cambio así logramos un impacto mucho mayor"1.

Esta idea se ve reforzada por Gustave Le Bon (1911), quien es citado por Mario Herreros (1989) al decir: "Para convencer a las masas es necesario: conocer sus sentimientos, fingir compartirlos e intentar modificarlos mediante: adecuación del mensaje a su particular psicología. Empleo de imágenes sugestivas. Satisfacción de sus necesidades" (p.115). No podría quedar más en claro lo que la contrapublicidad trata de hacer evidente.

\section{CONTRAPUBLICIDAD}

Ante esta idea del consumo como valor fundamental de la modernidad y que inicia un crecimiento desmedido en los años 60, fundamentalmente cuando la televisión pasa a ser un bien indispensable de la clase media, surgen los

1 Las campañas publicitarias de Benetton durante los años 90 utilizaron valores como el del multiculturalismo, el antirracismo, la unidad, etc.; pero en ningún momento publicitaron sus diseños, la idea era promover que quien utilizaba Benetton compartía esta visión. 
primeros movimientos de denuncia, que buscan transformar a la sociedad. Así, desde los grupos de arte callejero hasta los grupos sociales más organizados, empiezan a utilizar la contrapublicidad como una herramienta de denuncia.

Existe en este punto una distinción que es necesario realizar $y$ es la distinción entre este tipo de contrapublicidad y lo que autores como Doob han llamado contrapropaganda, que es cuando "un propagandista... intenta contrarrestar una propaganda competitiva realizada con anterioridad" (Doob en Herreros, 1989:84), la diferencia con la contrapublicidad es que el proceso de esta última es mucho más amplio y abierto a diversidad de personas $y$ grupos, siendo la finalidad poner en evidencia la manipulación más que "contrarrestar".

¿Cuál es entonces la intencionalidad de la contrapublicidad? La denuncia de una variedad de procesos detrás del consumo: la destrucción irresponsable de los recursos, la falta de responsabilidad social real de las compañías, la cultura del consumo y de la opulencia que se vende como liberadora, las relaciones de género desiguales $y$ discriminatorias, los roles de poder establecidos, los estereotipos de éxito social, la exclusión, la marginación y la mentira.

¿Cómo la contrapublicidad realiza esta denuncia? Alfonso Cortés (s.a.), argumenta que "la contrapublicidad es un discurso social que circula bajo la apariencia de un formato publicitario", utilizando los soportes y recursos que utiliza la publicidad, modificando las imágenes publicitarias del anunciante al que se quiere denunciar o creando una nueva y original campaña de denuncia. Naomi Klein, sin pretenderlo, plantea el principio fundamental de la contrapublicidad:

... a medida que los secretos que yacen detrás de la red mundial de las marcas sean conocidos por una cantidad cada vez mayor de personas, su exasperación provocará la gran conmoción política del futuro, que consistirá en una vasta ola de rechazo frontal a las empresas transnacionales $(2000: 15)$.

La organización "Consume Hasta Morir" define los contranuncios como respuestas de tipo comunicativo a la publicidad $y$ afirman que:

... no existe ninguna vía que no sea la propia publicidad para responder a la publicidad. (...) Los contranuncios son contestaciones a todo lo que hay detrás, es decir, a los modelos de vida, de consumo y de relacionarnos que plantea la publicidad ( $w w w$. consumehastamorir. com).

La contrapublicidad como herramienta de denuncia pública, ha sido utilizada en el ámbito de habla hispana por la organización "Consume Hasta Morir" de España, mientras que en el mundo angloparlante por "The Media Fundation" de Canadá o la "Billboard Liberation Front” de Estados Unidos. La gran herramienta de difusión de estas organizaciones ha sido Internet, por la rapidez y masividad de la difusión junto con los bajos costos de la misma. En Costa Rica no existen organizaciones dedicadas a crear $y$ difundir contrapublicidad, sin embargo existen "bloggeros" reconocidos como "el Chamuko" (http://infierno. ticoblogger.com) o páginas como la del grupo Fusil de Chispas (www.fusildechispas.com).

Lo más sobresaliente de este movimiento contrapublicitario es que los grupos $y$ las personas tienen la capacidad de confrontar y evidenciar lo que Naomi Klein (2000:18) llama "la red de logos", en tanto se comportan como "espías-arañas" que intercambian información con el resto de la sociedad.

Xesco Xasabuberta, quién se ha dedicado desde hace dos décadas a la creación de contrapublicidad, establece que:

... la publicidad y la contrapublicidad comparten un mismo lenguaje y un mismo objetivo, crear un impacto en el espectador; incluso utilizan los mismos recursos retóricos. Pero, así como el interés de la publicidad es el consumo irreflexivo, la contrapublicidad debe servirse del impacto inicial para provocar una reflexión. (...) la contrapublicidad no es una respuesta contra la publicidad o el 
consumo, sino una respuesta alternativa al consumismo irreflexivo (2007:16).

Así como para la publicidad el objetivo es vender, para la contrapublicidad el objetivo es denunciar $y$ hacer reflexionar.

LA CONTRAPUBLICIDAD ELECTORAL COMO ESTRATEGIA DE COMUNICACIÓN POLÍTICA

La Comunicación Política, tal y como es entendida hoy en día, trae implícito desde su definición, la persuasión de "las masas" por medio de la industria cultural y de los medios de comunicación. Esta persuasión tiene efectos evidentes sobre la cultura política de las sociedades. Siendo la persuasión su principal objetivo, encuentra en la contrapublicidad electoral una forma clara de resistencia a esa persuasión que se vale de los instrumentos de la publicidad comercial.

Las formas más usuales de comprender la Comunicación Política, están asociadas a los procesos de comunicación masiva que se dan en los contextos electorales y específicamente en los relacionados con los mensajes de publicidad política partidista, especialmente los televisivos y más recientemente, las estrategias de publicidad en línea. Justamente esta incursión de la Comunicación Política en la red, ha llevado a contratacarla por este mismo medio, que es el medio más utilizado por los movimientos sociales contrapublicitarios, específicamente por los bajos costos y la facilidad de acceso al medio.

Otra de las formas de comprender la Comunicación Política es la referente a los tips para lograr que los mensajes sean asertivos e impactantes; cómo hacer un "marketing político"2 que logre llevar a los candidatos a ganar unas elecciones por medio de la manipulación asertiva de las y los votantes. Los movimientos contrapublicitarios en sus páginas web y publicaciones brindan a las personas

$2 \quad$ Siguiendo a Mario Herreros (1989) el Marketing Político no es más que "la adaptación de la metodología y de las técnicas empleadas en la comercialización de los bienes y servicios en las sociedades de producción y consumo masivos" (p.157). tips para hacer evidente y así contratacar esta manipulación.

Si bien, el abordaje teórico de la comunicación y del marketing político ha sido reciente, su uso puede rastrearse desde los orígenes de la política. Gustavo Martínez (2004:23-24) hace un recuento y señala que desde la época de la polis griega en el Ágora, la comunicación era una "herramienta de estrategia política esencial" para participar a los ciudadanos (o al menos a aquellos considerados como tal) en la toma de decisiones; en otro momento explica como el Imperio Romano logró sostener su poderío, si bien por la fuerza militar, también por su capacidad de comunicación. En tiempos más recientes, Martínez señala que Nicolás Maquiavelo desde principios del siglo XVI "desarrolló una sofisticada teoría sobre el papel de la persuasión política como alternativa al uso de la fuerza" (2004:24), e incluso como Napoleón Bonaparte creó su propia oficina de comunicación, consciente del poder que tenía "el manejo de las masas".

Teóricos de la Comunicación Política la han definido como: un campo de estudio en el que se intercambia, mediante signos, señales o símbolos, las ideas y actitudes sobre asuntos públicos (Canel, 1999) y que en ese espacio se intercambian discursos contradictorios de los tres actores que legítimamente se expresan en público sobre la política: políticos, periodistas y opinión pública (Wolton, 1998); particularmente los mensajes elaborados por los políticos en sus campañas (del Rey, 1997).

A pesar de que en las definiciones queda manifiesto ese "enfrentamiento de mensajes opuestos", en el estudio de la Comunicación Política se deja siempre por fuera la reacción manifiesta de la sociedad ante los mensajes, decisiones $y$ acciones oficiales o hegemónicas, y es acá donde la contrapublicidad electoral al adversar y denunciar la manipulación de la publicidad electoral, es una categoría que debería ser incluida.

La Comunicación Política es hoy un asunto de mercadeo, donde hay un producto que vender a unos "consumidores electorales". La forma que adquiere el mensaje es variada, pero en una entrevista hecha por Dick Morris a 
Bob Goodman, reconocido publicista republicano, queda clara la forma que debe adquirir ese mensaje: "Yo trabajo con cuatro cosas y sólo cuatro cosas: el amor, la esperanza, el odio y el miedo" (Morris, 2002:375), es decir, que él básicamente trabaja con la emociones.

Esta es una de las evidencias de los nuevos rumbos que ha tomado la Comunicación Política desde su vertiente del marketing político, donde los mensajes, los instrumentos, los medios se han mecanizado, reedificado $y$ mercantilizado, $y$ han visto en la publicidad comercial y en los nuevos gurús mediáticos, un instrumento eficaz de dominación persuasiva.

\section{RECURSOS Y PROCEDIMIENTOS DE LA CONTRAPUBLICIDAD ELECTORAL ${ }^{3}$}

La contrapublicidad electoral parte de la concepción de que todo es una mercancía ${ }^{4}$ incluyendo a las y los candidatos políticos y sus propuestas. Las ofertas electorales, al igual que en el comercio, pasan a ser bienes, en igualdad de condiciones que la ropa de marca o los zapatos deportivos.

Esta línea difusa entre ambos conceptos ha llevado a que hoy día se hable solo de publicidad ("publicidad electoral", "publicidad institucional") en el tanto, no importa quién sea el emisor, el objetivo siempre es el mismo: atraer la atención, glorificar el producto y persuadir al receptor para su consumo.

La contrapublicidad electoral es una práctica de resistencia cultural, en tanto es una estrategia de apropiación, cambio o reconfiguración de las imágenes que proliferan en la esfera de la publicidad electoral, con el objetivo de desnudar sus verdaderas intenciones.

A continuación se ejemplifican tres grandes categorías de imágenes contrapublicitarias,

$3 \quad$ Las imágenes que se utilizan para ejemplificar esta sección han sido tomadas de diversas páginas de internet, que es el medio por excelencia para la transmisión de la contrapublicidad.

En: <http://noesunamanzana.blogspot. com/2008/02/Contrapublicidad-electoralelecciones.html> partiendo todas de la idea que "las imágenes no son meras ilustraciones, sino que poseen importante contenido" (Sturken y Cartwright, 2001:1); la primera, es el ataque directo a los procesos electorales como un todo $y$ a todos los actores políticos, participantes o no en el mismo; la segunda, tiene que ver con el uso y modificación de las imágenes de candidatos y candidatas a puestos electorales; la tercera, está enfocada en la modificación de eslóganes o textos publicitarios y por último, la alusión que está relacionada con distorsionar y restar credibilidad a algunas de las posturas programáticas de las y los candidatos.

La construcción de estas categorías enfatiza, siguiendo a Sturken y Cartwright (2001:45), que las imágenes generan significados, primero, por la forma en la que los receptores las experimentan y segundo, por el contexto en que dichas imágenes son vistas y esto es especialmente significativo en la contrapublicidad electoral en el tanto, el contexto de la justa electoral mueve más pasiones que otros periodos políticos.

\section{CATEGORÍA 1: EL ATAQUE DIRECTO A LOS PROCESOS} ELECTORALES

En esta categoría se ubican las imágenes contrapublicitarias que se enfocan en hacer una crítica a la legitimidad de los sistemas electorales, a los límites en las posibilidades de elección que tiene la ciudadanía, a la legitimidad del voto como ejercicio ciudadano, a los actores políticos participantes o no en el proceso. Esto a través de un llamado al abstencionismo y a la crítica del sistema político.

Este tipo de contrapublicidad electoral al denunciar un sistema pareciera que hace uso de procesos más de conciencia social que de confrontación, aún así permanece la idea de la persuasión contra todo aquello que se considera negativo.

La imagen 1 presenta un recipiente a manera de una urna de votación y haciendo uso del recurso de la metáfora o de una situación alegórica, lo iguala a un juguete de niños en el que existen piezas de diversas formas para ser 
introducidas en el agujero de la caja correspondiente a dicha forma. La paradoja surge cuando en la caja solo hay un tipo de agujero y fuera de la caja las piezas son diversas, ya que es una situación en que la imagen que acompaña al texto dice lo contrario al mismo. Se contradice la pluralidad del significante verbal y la única alternativa del voto, según el significante visual.

Se distinguen dos escenarios: el del mensaje denotativo verbal que habla de las elecciones como el instrumento privilegiado de la libertad de elección de una pluralidad bajo la vía democrática. Esto sería Comunicación Política tradicional si lo dejáramos a nivel del texto $y$ en el escenario denotativo.

En el escenario connotativo (el objetivo de quien realizó la imagen), es claro el montaje de que las elecciones nos llevan siempre a la misma opción, (todas las opciones son la misma), o que el sistema no funciona.

La paradoja también está en el hecho que pareciera que muy pocas piezas "calzan" en un sistema plural y democrático.

La imagen 2 presenta un grupo de retretes con las tapas abiertas. El uso de la metáfora, al igualar los retretes con las urnas de votación, es el recurso evidentemente utilizado en esta imagen contrapublicitaria.

Así el mensaje connotativo podría interpretarse como: "no importa por quién votes, en todos los casos estarás tirando tu voto al retrete". Nuevamente el mensaje alude al poco o nulo valor del voto como mecanismo de elección, a la idea de que todas las opciones son lo mismo y por último, que todas las opciones son un desecho, como programa electoral y por tanto, pueden ser tiradas al retrete.

La imagen 3 , es mucho más elaborada que las anteriores y tiene el propósito de realizar una sátira de las personas que en el marco de las elecciones presidenciales de 2010 en Costa Rica, participaron directa e indirectamente. Se aprecian de izquierda a derecha a: Rolando Araya, Jhonny Araya, Eugenio Trejos y Oscar López (excandidatos), Mario Quirós (exdiputado), Gloria Bejarano (diputada), "El Chamuko" creador de la imagen al centro, Laura Chinchilla (presidenta), Óscar Arias (expresidente); y jugando juegos de azar se

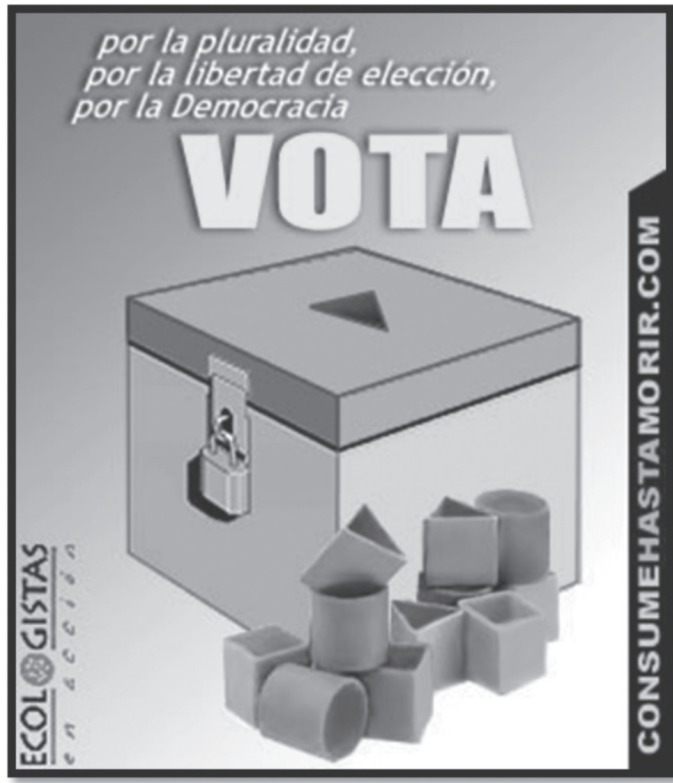

IMAGEN 1

CRÍTICA A LAS VOTACIONES COMO MECANISMO DE ELECCIÓN

Fuente: tomado de: <www.consumehastamorir.com>

encuentran Ottón Solís, Luis Fishman y Otto Guevara (excandidatos).

Existen además, otros elementos presentes en la imagen, que solo alguien que siga el pulso a los acontecimientos del ámbito político podría distinguir. Por ejemplo, la avioneta que se ve fuera de la ventana es la avioneta de la Fuerza Pública utilizada con fines proselitistas por la exdiputada Maureen Ballestero.

Otro elemento satírico tiene que ver con que la "Santa Cena Politiquera" se lleva a cabo en el Restaurante Cerutti, el mismo donde Clara Zomer (ex ministra de vivienda) gastó $\$ 627000$ colones en una sola comida con fondos públicos y al final, quedó impune.

Adornando las paredes, se encuentra a la izquierda, el "Neo Miguelangelo", luego que el retrato del expresidente Miguel Angel Rodríguez fuera rayado en la Asamblea Legislativa y a la derecha, la obra "Mazmorras" donde se aprecia "el futuro" del expresidente Rafael Angel Calderón.

Los recursos utilizados en esta imagen son múltiples, entre ellas, la alegoría, metáfora compleja e ironía, en el tanto, la vida política 


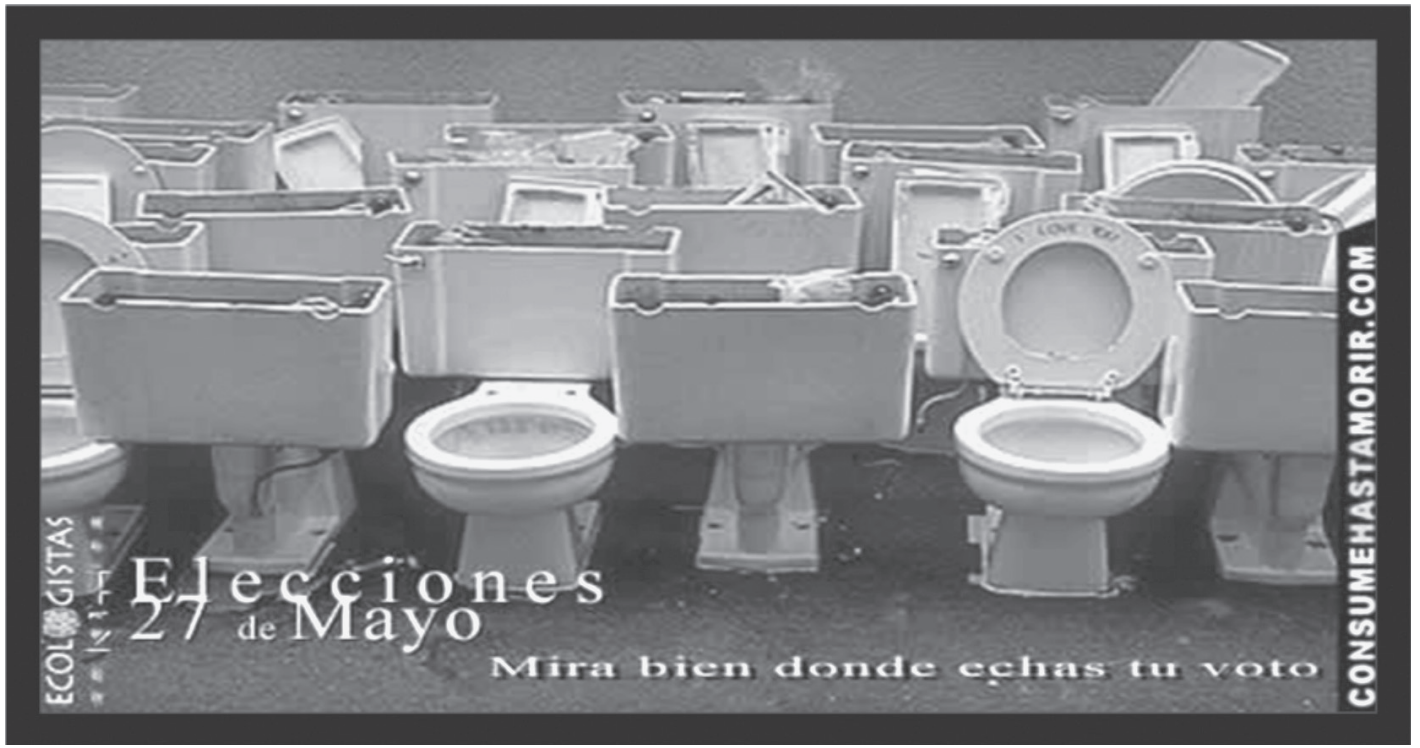

IMAGEN 2

RETRETES ELECTORALES

Fuente: tomado de: <www.consumehastamorir.com>

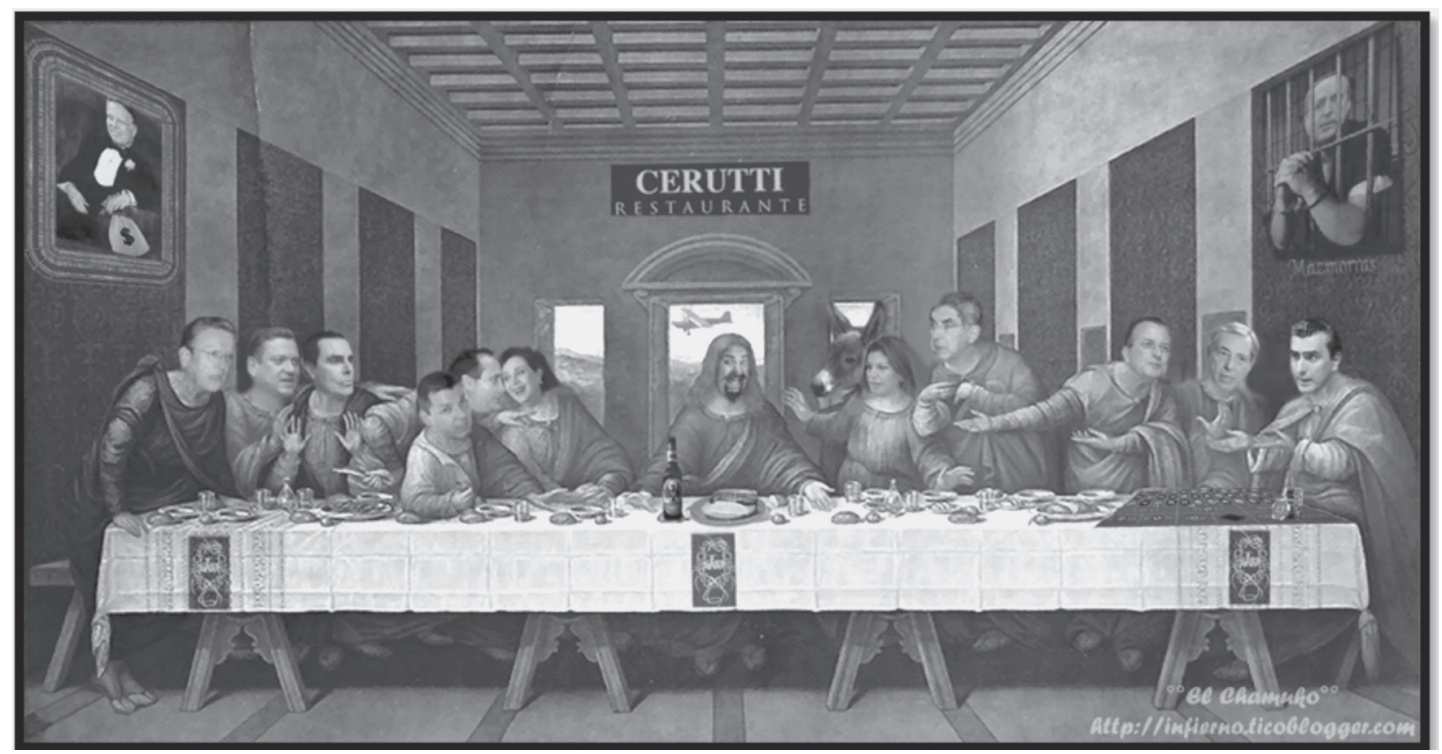

IMAGEN 3

SANTA CENA POLITIQUERA

Fuente: tomado de: <http://infierno.ticoblogger.com> 
tiene cualidades contrarias a las que se le podría atribuir a Jesús y a sus discípulos. La sátira está presente en la imagen como un todo, se satiriza a las personas a partir de la ironía.

\section{CATEGORÍA 2: MODIFICACIÓN DE LAS IMÁGENES DE CANDIDATOS Y CANDIDATAS}

Esta categoría pretende enfatizar en aquellas imágenes de contrapublicidad electoral, en donde la modificación de las imágenes de las y los candidatos tiene mayor impacto que cualquier modificación o adición del texto.

Esta contrapublicidad electoral, confronta a la ciudadanía con las "verdaderas" caras de las y los candidatos, como una forma de generar conciencia y cambio de comportamiento. El recurso fundamental es el de la sátira con propósito moralizador, lúdico o burlesco; usando la ironía y el sarcasmo.

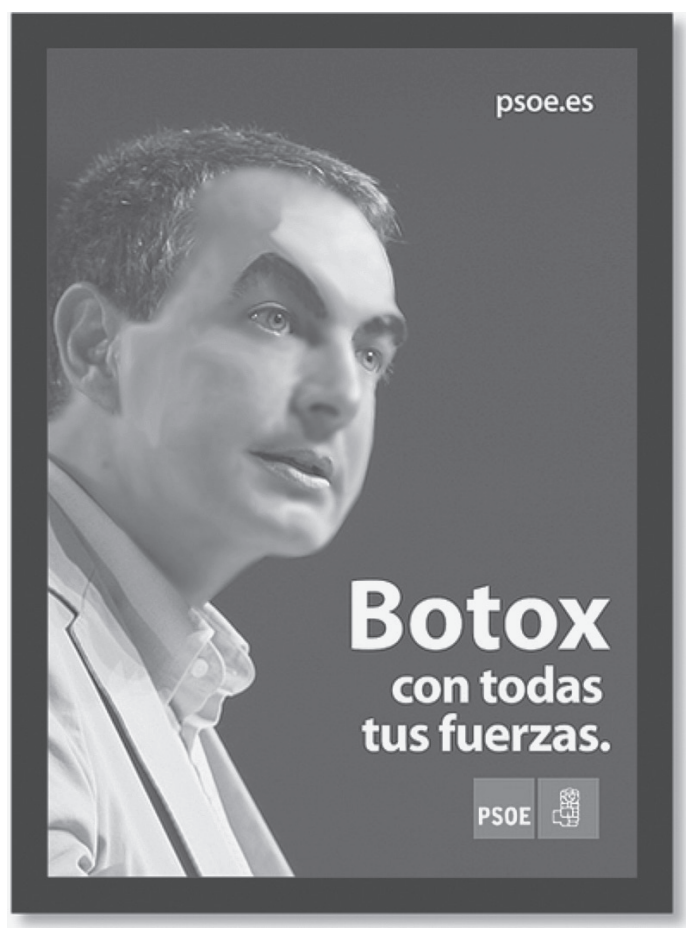

IMAGEN 4

ZAPATERO ESTIRADO

Fuente: tomado de: < http://noesunamanzana.blogspot. com/2008/02/Contrapublicidad-electoral-elecciones. html>
La imagen 4 es una crítica directa a la imagen de Zapatero en su candidatura. Hay un evidente uso de dos recursos: por un lado, del anclaje, ya que el texto explica la imagen, pero también la imagen permite explicar el texto. Por otro lado, se hace uso del recurso del relevo, en donde el texto sirve de anclaje para la imagen, aunque también aporta nuevos significados, transformando la palabra voto en botox lo que nos lleva a pensar en el voto como una forma de estirar algo, en este caso la permanencia de un tipo de partido $y$ de un tipo de política.

Otra clara lectura que se podría hacer de la imagen, es el "embellecimiento" artificial de la imagen pública de un candidato.

La imagen 5 solo puede comprenderse si se conoce bien la realidad política y el contexto electoral del país en ese momento. La candidata oficialista fue criticada, no por ser mujer, sino por constituirse en "la candidata de los

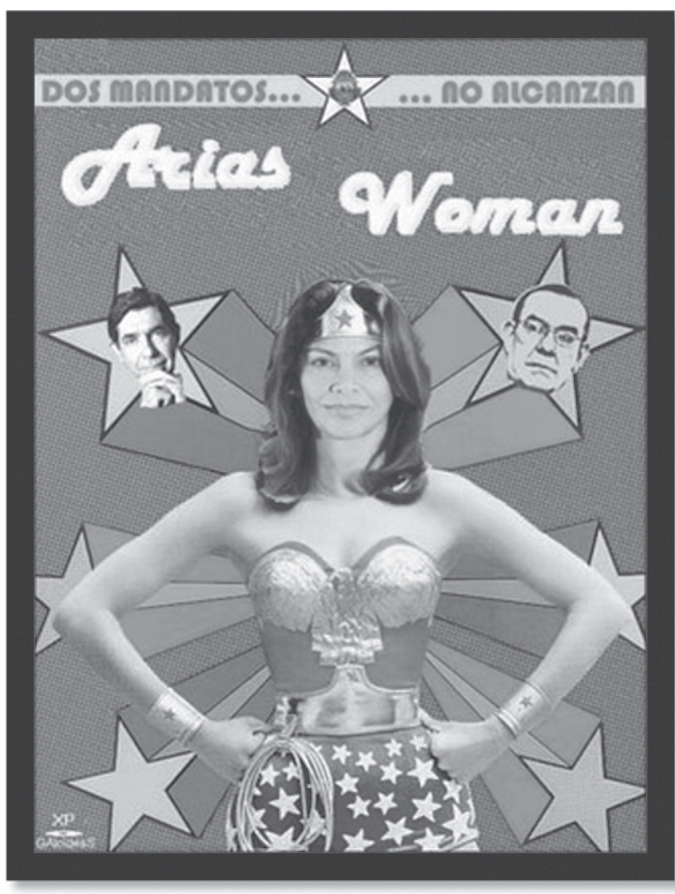

IMAGEN 5 ARIAS WOMAN

Fuente: tomado de: < http://infierno.ticoblogger.com> 
hermanos Arias". El texto refuerza la idea de continuidad al establecer que "dos mandatos no alcanzaban" refiriéndose a los dos periodos de Arias como presidente.

Así también, el uso de la alegoría de una heroína para hablar de una candidata que es la heroína salvadora de los Arias, para que de una $u$ otra forma puedan perpetuarse ellos en el poder. Esta manipulación de la candidata por el Presidente y su hermano es lo que esta imagen contrapublicitaria quiere evidenciar.

\section{CATEGORÍA 3: MODIFICACIÓN DE ESLÓGANES O TEXTOS PUBLICITARIOS}

Esta categoría parte de la idea de que en publicidad electoral o política, el eslogan es una parte fundamental, ya que al ser el elemento verbal de la imagen sintetiza la argumentación y los objetivos de la campaña electoral (Herreros, 1989: 287). Esta importancia, así como, la simpleza de los mismos, los hace objetos predilectos de la contrapublicidad electoral. Mientras que los textos de la publicidad electoral procuran exaltar las cualidades, capacidades y propuesta de las y los candidatos; la contrapublicidad electoral busca evidenciar falsedades en dicho texto. Contrario a la segunda categoría, la modificación del texto tiene mayor peso que la modificación de la imagen misma.

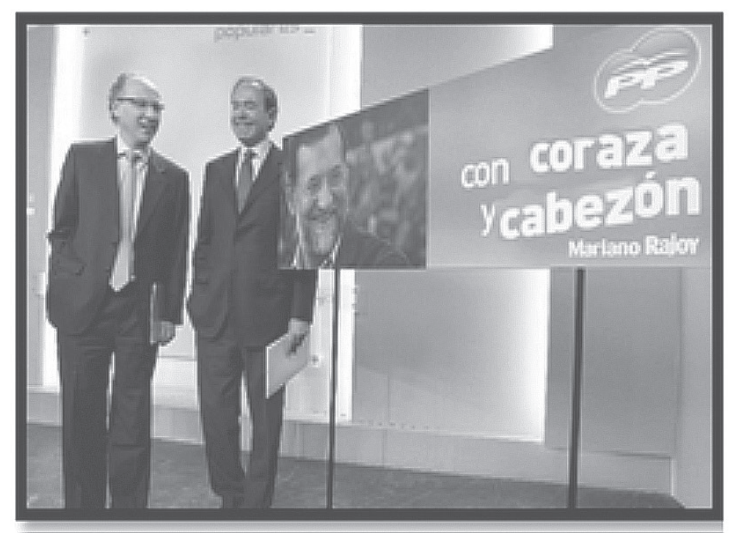

Las dos versiones de la imagen 6 , hacen referencia a una modificación del eslogan de Mariano Rajoy, el cual originalmente dice "Con cabeza y con razón", haciendo una clara alusión al conocimiento del candidato $y$ a sus propuestas.

La primera imagen es una modificación de una fotografía haciendo uso de medios digitales y modifica el eslogan para que diga "con coraza y cabezón”, siendo la intención describir un verdadero retrato psicológico del candidato. Esto se constituiría en una etopeya.

La segunda imagen es la modificación de una valla publicitaria, en la que se transforma el eslogan para que diga "sin cabeza, sin razón" volcando completamente el sentido original. Adicionalmente, se modifica la imagen del candidato colocándole un símbolo que representa a los curas de la iglesia católica y su conservadurismo, junto a un buitre en el hombro que simboliza corrupción.

La imagen 7 se vale del eslogan del movimiento del No al TLC y agrega la palabra "porqué" y el signo de pregunta después del NO para invertir el sentido original y cuestionar una posición política.

\section{CONCLUSIONES}

Una primera conclusión tiene que ver con el hecho que históricamente la sociedad

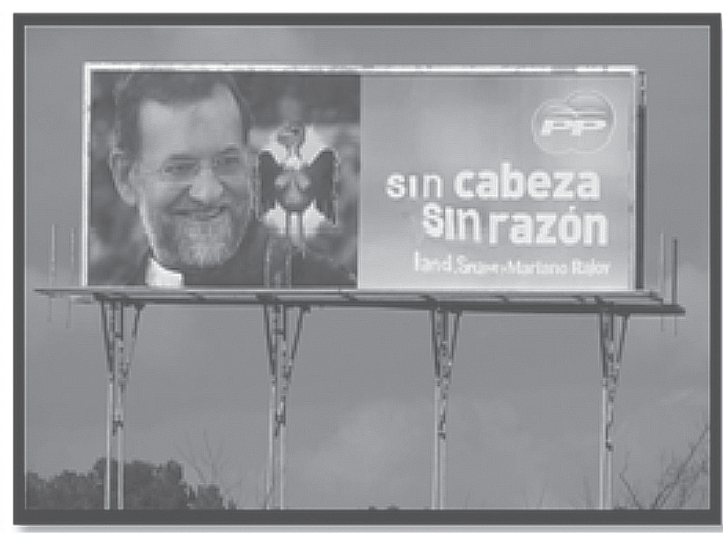

Fuente: tomado de: <http://noesunamanzana.blogspot.com/2008/02/Contrapublicidad-electoral-elecciones.html> 


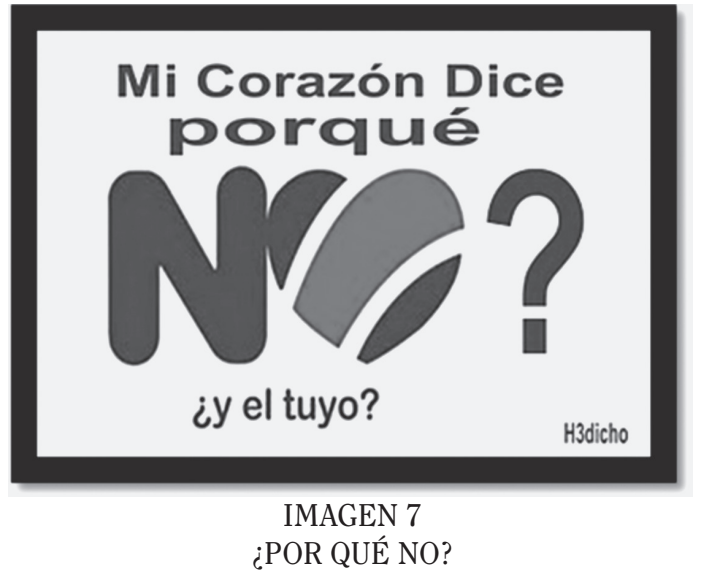

Fuente: tomado de: <www.blogalaxia.com/tags/pac>

estuvo dividida en dos mundos: el del consumo y el de la ciudadanía, sin embargo, los procesos y recursos publicitarios de ambos mundos se han ido homologando. El ciudadano pasa a ser consumidor y el voto que es un derecho pasa a ser una "moneda de cambio".

Una segunda conclusión lleva a pensar que un grupo de la ciudadanía busca transformaciones, de tal suerte que "podemos ver a los ciudadanos empezar a aplicar lo que han aprendido como consumidores en nuevas formas de activismo político" (Jenkins, 2006: 219) como la contrapublicidad.

...respuesta comunicativa y política enmarcada en el activismo social, que utiliza herramientas y recursos creativos similares y explora el mismo lenguaje empleado en los miles de anuncios que se vierten por los omnipresentes poros del aparato de comunicación comercial. Una respuesta que, en última instancia, busca subvertir a lo que contesta, promoviendo la reflexión y la construcción de una conciencia crítica (www.cHM).

La tercera conclusión requiere volver a la pregunta que se planteó al principio de este artículo: ¿por qué tratar de ligar a la contrapublicidad electoral con la Comunicación Política? Porque la contrapublicidad electoral sin un trasfondo ideológico y de transformación social se queda únicamente en forma y en estética, cuando en realidad la contrapublicidad electoral es evidentemente un arma de activismo socio-político, o al menos eso deja en evidencia el análisis de imágenes del apartado anterior. Pedro Ramiro dice en la Revista Malababa que:

...este tremendo potencial se puede desaprovechar si carece de un carácter político, $y$ es que la contrapublicidad ha de ser una herramienta más para la transformación social, porque como juego artístico-intelectual tiene el mismo interés que los pasatiempos del periódico. Así, la contrapublicidad aporta creatividad con un gasto mínimo de recursos, difunde una corrosiva ironía y contribuye a hacer una lectura distinta de la comunicación comercial, pero si no sirve para denunciar que la rueda del consumismo es social y ambientalmente insostenible, de poco vale (2007: 63).

Una cuarta conclusión está ligada con los soportes comunicativos de la contrapublicidad electoral, ya que si bien es cierto que la actual diversificación de los canales de comunicación que permite Internet otorga mayor posibilidad de crítica y diseminación de imágenes a bajo costo, sigue siendo desconocido el impacto real en la población versus el impacto de las campañas de publicidad electoral que bombardean al televidente día tras día. Así, Jenkins señala que "la difusión televisiva proporciona una cultura común, y la Web ofrece más canales localizados para responder a esa cultura" (2006: 222).

La quinta conclusión es sobre las limitaciones de la contrapublicidad electoral. Estas recaen en el mismo límite de lo simbólico, que si bien puede utilizarse para la transformación del pensamiento de las personas, para generar cambios reales $y$ palpables o para potenciar otras formas de pensar, tiene límites evidentes para lograr transformaciones reales en las prácticas y los comportamientos. Se podría incluso asegurar que los mensajes de texto $y$ las redes sociales tienen mayor poder de convocatoria.

Básicamente se debe ser realista y pensar que cambiar el poder hegemónico y sus prácticas es tremendamente difícil, principalmente 
porque este posee el control de los aparatos o de las instituciones (en este caso comunicativas) productoras de sentido, pero también por la seducción que generan las ofertas del poder hacia las personas.

La sexta conclusión está relacionada con la evidente realidad de que la contrapublicidad electoral crea reacciones muy diversas: risa, enojo, ofensa, preocupación. Esto es razonable en la medida que es diseñada justamente como una denuncia, pero también porque "nuestras experiencias visuales no tienen lugar en aislamiento, se enriquecen por recuerdos e imágenes de muchos $y$ diferentes aspectos de nuestra vida" (Sturken y Cartwright, 2001: 2), en otras palabras son vistas con todo un contenido ideológico que se ha ido construyendo cada persona.

La séptima conclusión tiene que ver con la importancia de la contrapublicidad electoral, que a pesar de sus limitaciones "simbólicamente representa, además, la lucha por uno de los pocos espacios (quizás el último) que aún permite la confrontación directa de discursos" (Rev. Malababa, 2007: 25). El valor de las imágenes de contrapublicidad electoral radica en el recurso del humor, la acidez y la ironía al servicio de la transformación social.

La última conclusión se acerca a una realidad poco prometedora y que ya ha sido evidenciada en la contrapublicidad comercial, por tanto de la que no deberíamos excluir es a la contrapublicidad electoral. Esta última, como práctica o cultura emergente, siguiendo la clasificación de Williams, trata de construir nuevos significados, valores, prácticas y relaciones, siempre corre el riesgo de ser absorbida y utilizada por la cultura hegemónica, y así perder su valor contestatario.

\section{BIBLIOGRAFÍA}

LIBROS

Canel, María José. Comunicación Política. Técnicas y estrategias para la sociedad de la información. Madrid, España: Editorial Tecnos SA., 1999.
Cortese, Anthony. Provocateur: images of women and minorities in advertising. Boston, Estados Unidos: Rowman \& Littlefield Publishers, 1999.

CHM. Contrapublicidad. Madrid, España: ConsumeHastaMorir Publicaciones, 2009.

Del Rey Morató, Javier. Los juegos de los politicos. Teoría general de la información y comunicación política. Madrid, España: Tecnos SA., 1997.

Herreros, Mario. Teoría y técnica de la propaganda electoral (Formas Publicitarias). Barcelona, España: ESRPPPU, 1989.

Klein, Naomi. No logo. Barcelona, España: Editorial Paidós, 2000.

Maarek, Philip. Marketing político y comunicación. Claves para una buena información política. Buenos Aires, Argentina: Paidós, 1997.

Martínez, Gustavo. Marketing político. Campañas, medios y estrategias electorales. Argentina, Buenos Aires: Ugerman Editor, 2004.

Morris, Dick. Juegos del poder. Ganar o perder: cómo juegan la partida los grandes líderes politicos de la historia. Buenos Aires, Argentina: El Ateneo, 2002.

Sassatelli, Roberta. Consumer culture: history, theory and politics. Londres, Inglaterra: Sage Publications, 2007.

Sturken, Marita y Cartwright, Lisa. Practices of looking: an introduction to Visual Culture. Estados Unidos: Oxford University Press, 2001.

Wolton, Dominique. "Las contradicciones de la comunicación política”. En: Gauthier, Gilles; Gosselin, André y Mouchon, Jean (comp.). Comunicación y política. Barcelona, España: Editorial Gedisa SA., 1998: 110-130.

Woodward, Ian. Understanding Material Culture. Londres, Inglaterra: Sage Publications, 2007.

\section{REVISTAS ELECTRÓNICAS}

Benetton, Luciano. "Entrevista". Revista El Mundo 95. Julio. 2001. 
Cortés, Alfonso. "Contrapublicidad y valores alternativos". Revista Electrónica Razón y Palabra 67. México (s.a.). En: <http:// www.razonypalabra.org.mx/N/n67/varia/ acortes.html>

Malababa (varios). "Malababa: contrapublicidad, resistencias y subculturas". Revista Electrónica 2. España, 2007. En: <http:// www.letra.org/spip/article.php?id_article $=2208>$

Romero, Verónica. "Publicidad y Consumo". Revista Comunicologi@: indicios y conjeturas. Primera Época 3. Publicación Electrónica del Departamento de Comunicación de la Universidad Iberoamericana, Ciudad de México. Primavera 2005. En: <http:// revistacomunicologia.org/index. php?option $=$ com_content $\&$ task $=v i e w \& \mathrm{i}$ $\mathrm{d}=99 \&$ Itemid $=86>$ [Consultada el $23 \mathrm{de}$ noviembre de 2010].

Fecha de ingreso: $07 / 03 / 2011$ Fecha de aprobación: 25/04/2011 
